\title{
The First S.A. Paraplegic National Games
}

\section{March, 1964}

\author{
By
}

ALFRED ROTHBERG, Vice-Chairman, S.A.S.P. Vice-Chairman S.A. Paraplegic Games Association.

The first S.A. Paraplegic Games, organized on a nationwide basis, and with participation from Southern Rhodesia, were held at the Wanderers' Club in Johannesburg. They truly made history. What the sponsors and the Executive of the Paraplegic Games Association had not expected even in their most hopeful dreams, has become reality. In less than fifteen months, almost out of nothing, a truly national organization has been created which was able not only to send a representative and most successful team to the International Games in Stoke-Mandeville, but also to put on the map our own National Paraplegic Games.

There is much we have to be thankful for. The support from the public was wholehearted. Commerce, Industry, Sport and Social Organisations, the Press and Radio, Government Departments, the Medical 'and the Paramedical Professions, to mention only a few, all rallied to the appeal to help brighten the lives of paraplegics and similarly handicapped persons. Perhaps most encouraging was the attitude of the S.A. Games Committee, which accepted without argument paraplegic sports and games as just another sporting activity. This became most evident, when at the presentation of awards the paraplegic champions received the same medals-Gold, Silver, and Bronze - as the ablebodied athletes.

The Paraplegic Games extended over three days. Six Regions-Southern Transvaal, Northern Transvaal, Western Province, Griqualand, Natal, and Rhodesia-took part, and nine international records were broken. The Southern Transvaal Region were hosts, and all the organizers, and the Committee of the Wanderers' Club, deserve highest praise for the competency with which attention was given to every detail. Spontaneous letters of appreciation from every participating region, received by the S.A. Paraplegic Games Association, prove that competitors, escorts and supporters all regarded these games as a memorable event.

We trust that from these Games inspiration will come to those paraplegics who until now thought that participation in sport and games was outside their grasp. We shall certainly try to advance every paraplegic sportsman to the highest degree of his or her potential. But no one not coming up to the high International Stoke Mandeville standards need be despondent. We shall find adapted, adjusted, and additional activities which will make it possible for handicapped people of any degree of disability to enjoy participation under rules designed to leave no one outside the aims of the S.A. Paraplegic Games Association. On the other hand, numbers of paraplegics have achieved such a degree of mobility and ambulation, that they are reluctant to use a wheelchair just for the purpose of participating in paraplegic games and sports. For them, too, adequate outlets for their energy must be found, and competitions in the standing, position with appropriate supports may have to be evolved. We owe much to the Stoke Mandeville Rules, and we are following them ardently. However, in South Africa, we encounter some problems of our own. Especially where we have to deal with Non-European participants, we frequently come up against a certain dislike or lack of understanding of the value of formal athletics, governed by established rules. These participants seem more easily attracted by competitive activities containing an element of play. Perhaps, in due course, we may be able to contribute our share to the development of paraplegic activities by increasing their scope.

Physiotherapy and physiotherapists in the past have been privileged to play an important part in the rehabilitation of paraplegics. In this field, physiotherapists stand side by side with the representatives of many other callings. Their concerted effort is bound to produce formidable results.

The preparations for the S.A. Paraplegic National Games for Non-Whites are nearly completed. These Games are scheduled for May 9th, 1964, at the Baragwanath Sports Field. Here, too, great enthusiasm has been shown. Participants will come from the Western Province, Orange Free State, Northern Transvaal and Southern Transvaal. The number of entries is most encouraging. The Press, and this includes the Bantu Press in particular, have drawn the public's attention to the importance of sports activities for paraplegics and have prepared the ground well. Thousands of Non-White spectators watched the wheel-past of a team of paraplegic sportsmen at the opening of the Non-White S.A. National Games, and greeted them with acclamation. It is hoped that the Non-White Paraplegic Games will prove to be an important milestone in the advancement of the cause of the paraplegics.

\section{P.S.-}

Since this article went to press, the Non-White National Paraplegic Games have been completed, too. They were, indeed, an unqualified success. In an atmosphere of camaraderie, goodwill, friendliness and good sportsmanship, contests in archery, table-tennis, javelin, discus, club throwing, and putting the shot took place, and culminated in the finals of the Basket Ball match. Participants and spectators alike enjoyed every phase of the Games. The presentation of awards by the Chairman of the Non-White Games Committee closed a meeting which augurs well for the future. 